\title{
Membangun Komunikasi Kesehatan Perilaku Hidup Bersih dan Sehat di Sekretariat Daerah Kabupaten Tanah Laut
}

\author{
M. Noveriyadie, Sjaiful Jayadiningrat, Noormarizqa Puspaningratri, \\ Marhaeni Fajar Kurniawati
}

Program pasca sarjana ilmu komunikasi Universitas Islam Kalimantan Muhammad Arsyad Al Banjari

Email author: paovelab@gmail.com, jayadiningratsjaiful@gmail.com, rizqa.id@ gmail.com, marhaeni.akbar@gmail.com

\begin{abstract}
ABSTRAK
Adanya pandemi covid-19 dinilai memunculkan paradigma dan pola pikir baru bagi masyarakat di Kabupaten Tanah Laut, selama ini masyarakat belum sepenuhnya memahami Perilaku Hidup Bersih dan Sehat (PHBS). Munculnya covid-19 ini seperti menjadikan momentum untuk membangun dan mengedukasi masyarakat berperilaku hidup sehat. Kasus maraknya virus corona memang berdampak luas, tapi itu berkat publikasi yang terkesan terus menerus dan berkepanjangan. Beberapa kasus lain seperti HIV/AIDS, demam berdarah, dan penyakit kronis lain yang tinggi angka kematiannya seolah tidak terdengar lagi semenjak corona ini merebak. Rekomendasi pemerintah yang terusmenghimbau gerakan PHBS serta keluarga yang memiliki kesepakatan bersama dalam gerakan hidup sehat menjadi kunci pencegahan penyebaran Covid-19 pada masa pandemik ini. Melakukan PHBS diharapkan penyebaran Covid-19 dapat dihambat sehingga kejadian tidakmenambah angka terkonfirmasi. Kantor pemerintahan pun mulai menunjukkan hal baru. Beberapa titik di kantor Sekretariat Daerah Tanah Laut misalnya, kini dipasangi fasilitas hand sanitizer, yakni cairan antiseptik untuk pembersih tangan. Ini dilakukan dalam upaya mewujudkan prilaku hidup bersih dan sehat, sebagai upaya mengantisipasi pencegahan wabah corona dilingkungan sekretariat daerah kabupaten tanah laut.
\end{abstract}

Kata Kunci: PHBS, Covid-19, Kantor Pemerintahan, Kantor Sekretariat Daerah

\section{PENDAHULUAN}

Klaster perkantoran masih jadi ancaman dan hingga saat ini menjadi perhatian serius. Penyebab tingginya kasus klaster ini, selain kondisi perkantoran yang tertutup dan sirkulasi tidak lancar, banyak orang berkumpul dalam waktu yang lama di ruangan yang sama. Kemudian karena merasa di kantor relatif lebih aman, banyak yang lengah dan abai terhadap protokol kesehatan. Jika ada pekerja yang tertular, baik berasal dari rumah atau perjalanan menuju kantor dengan kendaraan umum, pekerjaan tersebut akan sangat mudah menularkan ke orang yang kontak dekat dengannya di kantor.Maka dari itu, melaksanakan protokol kesehatan melalui penerapan Perilaku Hidup Bersih dan Sehat(PHBS) secara konsisten menjadi upaya pencegahan Covid-19 yang penting di perkantoran, pabrik, atau tempat kerja lainnya. Setiap pekerja dan seluruh orang yang berada di tempat kerja harus mau dan mampu menerapkan PHBS sehingga dapat mencegah terjadinya penularan Covid-19.Menurut Kementerian Kesehatan RI, PHBS adalah semua perilaku kesehatan yang dilakukan karena kesadaran pribadi sehingga keluarga dan seluruh anggotanya mampu menolong diri sendiri pada bidang kesehatan serta memiliki peran aktif dalam aktivitas masyarakat.

Dalam menghadapi wabah Covid-19 ini, perlu adanya perubahan sikap dari setiap orang dalam hal menjaga kesehatan tubuhnya masing-masing. Selain berbagai cara yang dianjurkan untuk mencegah terjadinya penularan Covid-19, mengubah kebiasaan negatif 
menjadi kebiasaan yang berdampak positif bagi dirinya sendiri sangat membantu dalam meminimalisir penularan wabah penyakit ini. Pada kenyataannya banyak opini bertentangan dari setiap individu di media masa yang telah tersebar luas yang berpotensi memberikan infomasi tidak tepat (Ratzan, 2020).

Mengatasi hal tersebut, strategi telah ditempuh oleh setiap kelompok wilayah maupun instansi untuk mengurangi penyebaran Covid-19. Upaya itu dapat dikategorikan sebagai komunikasi kesehatan yang dipandang penting untuk menyediakan akses seperti informasi kesehatan masyarakat, pendidikan, dan peningkatan literasi kesehatan (Zhu, 2020).Komunikasi kesehatan dapat diartikan sebagai sebuah aplikasi dari konsep dan teori komunikasi dalam transaksi yang berlangsung antarindividu /kelompok terhadap isu-isu kesehatan (Hendariningrum, 2018). Komunkasi kesehatan diartikan pula sebagai penggunaan strategi komunikasi untuk menyebarkuaskan informasi kesehatan yang memengaruhi, dan memotivasi individu, komunitas, maupun institusi untuk membuat keputusan yang erat hubungannya dengan bidang kesehatan (Aditya., 2020). Salah satu strategi komunikasi kesehatan yang dianjurkan yaitu dengan menerapkan PHBS atau Perilaku Hidup Bersih dan Sehat.

Menurut Kementerian Kesehatan (2015), PHBS merupakan perilaku kesehatan yang dilakukan oleh kesadaran diri-sendiri, sehingga dapat menularkan kebiasaan yang positif kepada keluarga dan juga lingkungan masyarakat perihal menjaga kesehatan. Penerapan PHBS sangat dianjurkan kepada seluruh masyarakat di Indonesia meskipun ada atau tidaknya wabah Covid-19. Hal ini dikarenakan menjaga imunitas tubuh sangat penting agar tubuh tetap sehat dan terhindar dari penyakit. Akan tetapi, masih sangat banyak masyarakat Indonesia yang belum paham akan pentingnya pola hidup yang sehat.

\section{METODE PENELITIAN}

Artikel ini menggunakan jenis penulisan kualitatif yang bersifat studi pustaka (library research) yang mengunakan buku-buku dan literatur-literatur lainnya sebagai objek utama. Sumber data yang digunakan dalam penelitian kepustakaan ini adalah literatur-literatur yang berkaitan dengan Perilaku Hidup Bersih dan Sehat atau PHBS. Teknik pengumpulan data dalam penelitian ini adalah dengan mengumpulkan buku, jurnal, makalah, website, dan informasi lainnya yang berkaitan dengan judul artikel untuk mencari data yang berkaitan dengan PHBS, Covid19,dilingkungan kantor pemerintah yang setelah itu langkah yang dilakukan adalah dengan memilih data-data tersebut kemudian menganalisis dan mengolahnya agar penyajian data ringkas dan sistematis. Dalam penelitian ini teknik analisis data menggunakan model Miles dan Huberman yang terdiri dari tiga alur kegiatan, yaitu reduksi data, penyajian data, dan penarikan kesimpulan/verifikasi. Prosedur pelaksanaan penulisan artikel yaitu dengan mencari literatur-literatur yang berkaitan dengan pembahasan, baik buku, jurnal, website, dan lain sebagainya. Setelah melakukan pencarian, kemudian mengkaji dan menganalisis literatur mana yang akan dipakai dan dimasukkan kedalam artikel. Kemudian, melakukan pembahasan dan membuat kesimpulan.

\section{HASIL DAN PEMBAHASAN}

Berdasarkan hasil pengumpulan data dan analisis yang telah dilakukan, terdapat banyak penelitian yang telah membahas mengenai Perilaku Hidup Bersih dan Sehat, namun hanya beberapa yang mengaitkannya dengan pandemi Covid-19, selain itu masih sedikit yang mengaitkan keduanya dengan lingkungan masyarakat secara umum. Covid-19 Corona Virus Disease 2019 atau COVID-19 adalah jenis penyakit baru yang disebabkan oleh infeksi Virus Severe Acute Respiratory Syndrome Coronavirus 2 (SARSCOV-2) atau yang dikenal dengan 
novel coronavirus (2019-nCoV) (Singhal, 2020). Penyakit ini ditularkan melalui droplet (percikan) pada saat berbicara, batuk, dan bersin dari orang yang terinfeksi virus Corona. Selain itu penyakit ini juga dapat ditularkan melalui kontak fisik (sentuhan atau jabat tangan) dengan penderita serta menyentuh wajah, mulut, dan hidung oleh tangan yang terpapar virus Corona (Singhal, 2020). Prinsip pencegahan penularan COVID-19 pada individu dilakukan dengan menghindari masuknya virus melalui ketiga pintu masuk dengan beberapa tindakan, seperti:

a. Menggunakan alat pelindung diri berupa masker yang menutupi hidung dan mulut hingga dagu, jika harus keluar rumah atau berinteraksi dengan orang lain yang tidak diketahui status kesehatannya (yang mungkin dapat menularkan COVID-19). Apabila menggunakan masker kain, sebaiknya gunakan masker kain 3 lapis.

b. Membersihkan tangan secara teratur dengan cuci tangan pakai sabun dengan air mengalir atau menggunakan cairan antiseptik berbasis alkohol/handsanitizer. Selalu menghindari menyentuh mata, hidung, dan mulut dengan tangan yang tidak bersih (yang mungkin terkontaminasi droplet yang mengandung virus).

c. Menjaga jarak minimal 1 meter dengan orang lain untuk menghindari terkena droplet dari orang yang bicara, batuk, atau bersin, serta menghindari kerumunan, keramaian, dan berdesakan. Gejala klinis yang muncul akibat terinfeksi virus ini seperti gejala flu biasa (demam, batuk, pilek, nyeri tenggorokan, nyeri otot, nyeri kepala) hingga komplikasi berat (diare dan pneumonia) hingga menyebabkan kematian (Huang dkk, 2020: Chen 2020).

\section{Perilaku Hidup Bersih dan Sehat}

PHBS (Perilaku Hidup Bersih dan Sehat) merupakan sekumpulan perilaku yang dipraktikkan atas dasar kesadaran sebagai hasil pembelajaran yang menjadikan seseorang, keluarga, kelompok atau masyarakat agar mampu menolong dirinya sendiri (mandiri) di bidang kesehatan dan berperan aktif dalam mewujudkan kesehatan masyarakat (Peraturan Menteri Kesehatan Republik Indonesia Nomor 2269).

Di tempat kerja, pada dasarnya PHBS merupakan sebuah upaya untuk memberdayakan, mengetahui, mau, dan mampu untuk mempraktikkan perilaku hidup bersih dan sehat guna mencegah penularan penyakit, dalam hal ini Covid-19.

Manfaat PHBS di tempat kerja, antara lain:

1. Meningkatnya kesadaran pekerja akan kesehatan

2. Pekerja dapat secara mandiri melakukan tindakan preventif guna mencegah penularan Covid-19

3. Meningkatnya produktivitas kerja

4. Menciptakan lingkungan kerja yang sehat

5. Meningkatnya kualitas hidup.

Menurut Razi dkk. (2020), perilaku hidup bersih dan sehat (PHBS) untuk pencegahan virus COVID-19 dapat berupa cara mencuci tangan yang baik dan benar, cara menerapkan etika batuk, cara melakukan Physical Distancing (menjaga jarak fisik), dan cara menjaga kebersihan diri. Pemberian edukasi mengenai PHBS ini dapat dilakukan dengan penyuluhan atau dengan menggunakan media berupa poster. 


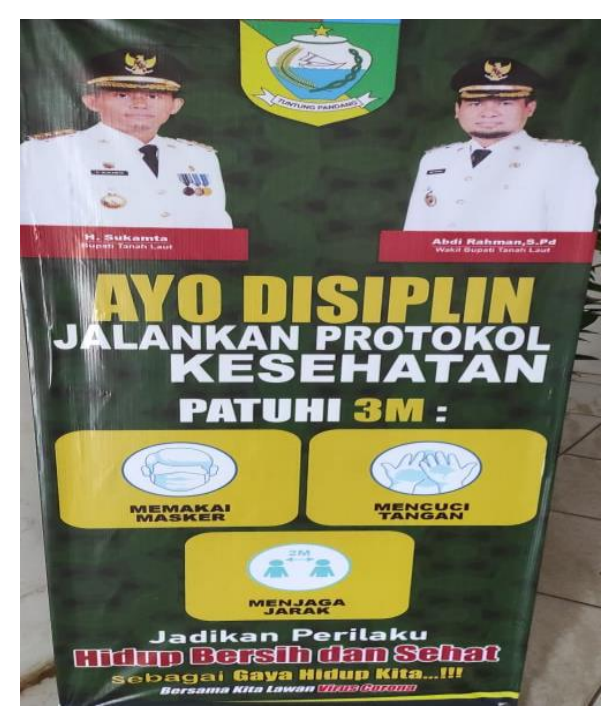

Gambar 1. Contoh PHBS

\section{Memakai masker}

Masker menjadi salah satu benda yang wajib dikenakan. Anda bisa mengenakan masker kain non medis atau disesuaikan dengan jenis pekerjaan Anda. Masker wajib dikenakan sejak perjalanan dari atau ke rumah dan selama di tempat kerja.Penggunaan masker sangat penting untuk melindungi diri sendiri karena mencegah masuknya droplet yang keluar saat kita batuk, bersin, atau berbicara sehingga kita tidak tertular. Masker juga sangat berguna untuk melindungi orang lain karena menahan droplet yang keluar saat kita batuk, bersin, atau berbicara sehingga tidak menularkan virus kepada orang lain.

\section{Menjaga jarak \& menghindari kerumunan}

Droplet yang keluar saat kita batuk, jika tanpa masker bisa meluncur sampai 2 meter. Ketika berbicara tanpa masker, aerosol (uap air) bisa meluncur sejauh 2 meter. Saat bersin tanpa masker, droplet bisa meluncur sejauh 6 meter.

Dengan menjaga jarak, kita bisa mengurangi risiko tertular/menulari. Perusahaan bisa mengeluarkan peraturan yang mendorong pekerjanya agar menerapkan protokol kesehatan menjaga jarak, di antaranya:

- Menjaga jarak antrean di pintu masuk, mematuhi penanda lantai yang tersedia

- Menjaga jarak di lift dengan posisi berdiri saling membelakangi

- Menjaga jarak dengan rekan kerja minimal 1 meter

- Mengatur tempat duduk agar berjarak 1 meter pada meja/area kerja, saat melakukan meeting dan saat istirahat.

- Membatasi jumlah peserta rapat

- Mengeluarkan protokol tidak makan/minum bersama

- Membentuk Satgas Covid-19

\section{Mencuci tangan pakai sabun (CTPS)}

Virus mati dengan sabun dan air mengalir. Lakukan 6 langkah cuci tangan dengan benar, yaitu cuci tangan pakai sabun dan air mengalir selama minimal 20 detik, atau cuci tangan dengan hand sanitizer dengan kandungan alkohol minimal 60\%.Pekerja harus patuh mencuci tangan saat tiba di tempat kerja, sebelum makan, setelah kontak dengan pelanggan/pertemuan dengan orang lain, setelah dari kamar mandi, setelah memegang benda yang kemungkinan terkontaminasi. 


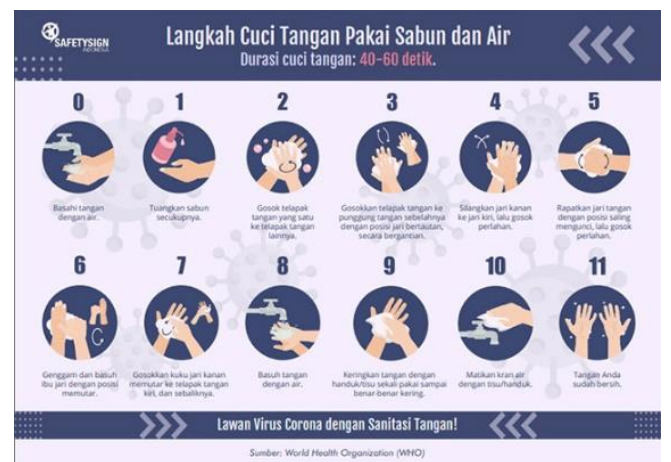

Gambar 2. Contoh PHBS mencuci tangan

\section{Menerapkan etika batuk}

Membudayakan etika batuk (tutup mulut dan hidung dengan lengan atas bagian dalam) dan jika menggunakan tisu untuk menutup batuk dan pilek, buang tisu bekas ke tempat sampah yang tertutup dan cuci tangan dengan sabun dan air mengalir setelahnya.

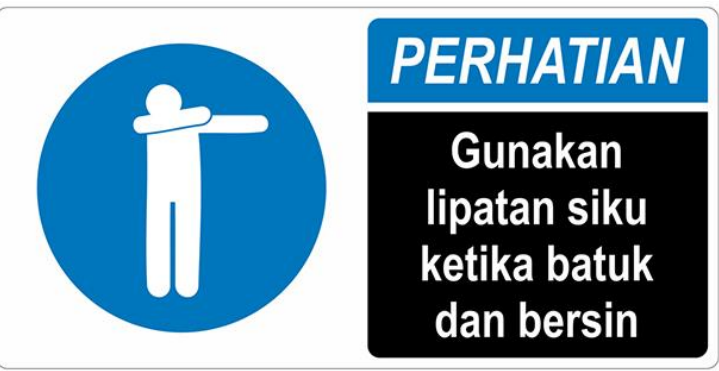

Gambar 3. Contoh PHBS Etika Batuk

\section{Melakukan olahraga rutin}

Anda dapat melakukan olahraga bersama sebelum kerja dengan tetap menjaga jarak aman atau olahraga sendiri minimal 30 menit per hari dan anjuran berjemur matahari selama 5-15 menit, 2-3 kali seminggu.

\section{Makan makanan dengan gizi seimbang}

Dengan menerapkan pola makan sehat dan penuh nutrisi, kualitas kesehatan dan daya tahan tubuh sudah pasti ikut meningkat. Salah satu makanan yang baik untuk daya tahan tubuh adalah makanan kaya akan vitamin $\mathrm{C}$ dan vitamin $\mathrm{B}$ kompleks.

\section{Menyentuh barang di tempat-tempat tertentu}

Tanpa sadar, Anda kerap menyentuh barang atau benda-benda di tempat umum seperti tombol lift, gagang pintu atau pegangan tangga. Gunakan siku untuk membuka pintu dan menekan tombol lift.Jika terpaksa harus menggunakan absensifinger print, gunakan hand sanitizer setelahnya. Sebaiknya Anda juga rutin membersihkan gagang pintu, tombol lift, keyboard komputer, mouse, atau telepon genggam menggunakan tisu basah atau disinfektan setiap 4 jam sekali.

\section{Penggunaan alat pribadi secara bersama-sama}

Hindari penggunaan alat pribadi secara bersama seperti alat salat, alat makan, dan lain-lain. 


\section{Menyentuh wajah}

Tidak menyentuh wajah atau mengucek mata dengan tangan, gunakan tisu bersih jika terpaksa.

\section{Menggunakan transportasi umum}

Upayakan tidak menggunakan transportasi umum, jika terpaksa menggunakan transportasi umum:

- Tetap menjaga jarak dengan orang lain minimal 1 meter

- Upayakan tidak sering menyentuh fasilitas umum, gunakan hand sanitizer

- Gunakan helm sendiri

- Upayakan membayar secara non tunai, jika terpaksa memegang uang gunakan hand sanitizer

- Tidak menyentuh wajah atau mengucek mata dengan tangan, gunakan tisu bersih jika terpaksa.

Pandemi Covid-19 memang mewajibkan siapa saja untuk waspada. Dengan protokol yang tepat dan efektif, pekerja dan seluruh orang yang berada di tempat kerja pun dapat tetap aman, sehat, dan produktif bila disiplin menerapkan itu.

\section{KESIMPULAN}

Pandemi Covid-19 memang mewajibkan siapa saja untuk waspada. Dengan protokol yang tepat dan efektif, pekerja dan seluruh orang yang berada di tempat kerja pun dapat tetap aman, sehat, dan produktif sebagai upaya keselamatan dan kesehatan kerja di perkantoran yang sangat penting untuk melindungi pekerja dari segala gangguan akibat proses kerjanya, demi terwujudnya lingkungan kerja yang sehat, bugar dan produktif diperlukan adanya komitmen dari pimpinan dan seluruh pegawai. Komunikasi Kesehatan Perilaku Hidup Bersih dan Sehat yang ada di Sekretariat Daerah Kabupaten Tanah Laut terlihat dari adanyabanner dan poster himbauan untuk mematuhi protokol kesehatan. Upaya Komunikasi Kesehatan di lingkungan Sekretariat Daerah Tanah Laut diharapkan dapat melindungi seluruh pegawai dalam setiap aktivitasnya.

\section{DAFTAR PUSTAKA}

Aditya, K. (2020). Komunikasi Kesehatan pada Program Pemanfaatan Sarana dan Prasarana Desa Rawabogo untuk Kebutuhan Masyarakat Menuju Kehidupan yang Sehat. Journal Pengabdian kepada Masyarakat USB. 2(1). Diakses pada 24 April 2021 melalui: http://183.91.79.105/index.php/Abdimas_Sang_Buana/article/view/505/268

Hendariningrum, R. (2018). Budaya dan Komunikasi Kesehatan (Studi Pandangan Kesehatan pada Masyarakat Sunda Dalam Tradisi Makan Lalapan). Jurnal Lugas. 2(1). Diakses pada 25 April 2021 melalui: http://ojs.stiami.ac.id/index.php/lugas/article/view/118/103

Mulyadi, H.D., Laras, N.A., Muhammad A.R., Naufal, A., Sekar., W.T., Prasetyo., L., (2020). Pentingnya Penerapan Phbs Dalam Menghadapi Pandemi Covid-19 Di Lingkungan Masyarakat. Jurnal Unnes.. Unnes.ac.id.

Laturrakhmi, Y. F., Sinta, S., Nilam W.. (2019). Analisis Perilaku Masyarakat Pedesaan terhadap Asuransi Kesehatan Nasional dalam Perspektif Komunikasi Kesehatan. Jurnal Komuniti. 11(2). Diakses pada 25 April 2021 melalui: http://journals.ums.ac.id/index.php/komuniti/article/view/10040/5546

Palilu, H. I., August, J.P. dan Grace, D.K. (2015). Gambaran Perilaku Hidup Bersih Dan Sehat Pada Pegawai Di Kantor Dinas Kesehatan Kota Manado. Jurnal Kedokteran Komunitas 
Dan Tropik . 2(3).Diakses melalui:

https://ejournal.unsrat.ac.id/index.php/JKKT/article/view/7778

Raztan, S.C., Silvia S., dan Lauren Rauh. (2020). Enhanching Global Health Communication during A Crisis: Lesson from The Covid-19 Pandemic. Public Health Research \& Practice. 30 (2). Diakses pada 24 April 2021 melalui: https://academicworks.cuny.edu/sph_pubs/265/

Syairozi, M. I. (2011). Analisis peranan sektor pertanian terhadap produk domestik regional bruto (PDRB) di kabupaten Malang (periode 2000-2008) (Doctoral dissertation, Universitas Negeri Malang).

Syairozi, M. I. (2019). Pengungkapan CSR pada Perusahaan Manufaktur dan Perbankan: Tidar Media. Tidar Media.

Wahyudin, U. (2016). Membangun Model Kampanye Komunikasi Kesehatan PHBS di Jawa Barat. Jurnal Ilmu Politik dan Komunikasi. 2(7). Diakses melalui: http://10.34010/jipsi.v6i2.319?

Wati, P.D.C.A., dan Ilham A.R. (2020). Perilaku Hidup Bersih dan Sehat pada Masyarakat di Kelurahan Rangkah Kota Surabaya. Jurnal Promkes. 8(1). DOI: http://10.20473/jpk.V8.L1.2020.47-58

Zhu C. Xiaolin X., Wei Z., Jianmin, C., dan Richard E.(2020). How Health Communication via Tik Tok Makes a Difference: A Content Analysis of Tik Tok Accounts Run by Chinese Provincial Health Committees. Journal Environtement Res. Public Health. 17(1).

Diakses melalui: https://doi.org/10.3390/ijerph17010192

Sumiati, E. (2019). Sosialisasi dan Advokasi PHBS di Perkantoran, Demi Wujudkan Kesehatan dan Keselamatan. Info Publik Solo. Diakses melalui: https://infopublik.solokkota.go.id/sosialisasi-dan-advokasi-phbs-di-perkantoran-demiwujudkan-kesehatan-dan-keselamatan-kerja/

Pentingnya Penerapan Phbs Dalam Menghadapi Pandemi Covid-19 Di Lingkungan Masyarakat. Jurnal Unnes.

Panduan Perilaku Hidup Sehat dan Bersih Di Tempat Kerja Saat Pandemi, Ini yang Perlu Diterapkan!by Safety Sign Indonesia | Nov 2, 2020 | Safety Article 